\title{
Operative and Non-Operative Management of Blunt Liver Trauma: Our Experience
}

\author{
MOHAMED H. ZAID, M.D; MOHEB S. ESKANDAROS, M.D. and AHMED A. DARWISH, M.D. \\ The Department of General Surgery, Ain Shams University, Egypt
}

\begin{abstract}
Background: In recent years, there is a success of Nonoperative management of blunt liver trauma.

Aim of Study: The aim of our study is to discuss our experience in Operative and Non-Operative management of Blunt liver Trauma.

Patients and Methods: A prospective cohort enrolled twentyseven patients with blunt liver trauma admitted to our hepatobiliary unit were managed with non-operative conservative management, Angioembolization or operative intervention.

Results: The patients mean age was $31.1 \pm 7.51$ years. Two (7.4\%) patients were diabetic, three $(11.1 \%)$ were hypertensive. Twenty-two $(81.5 \%)$ patients Glasgow coma score $>10$. Twenty (74\%) patients were managed Non-operatively. Nineteen $(95 \%)$ patients had successful Non-operative management but one patient $(5 \%)$ patient needed delayed operation. Seven (25.9\%) patients were managed operatively. The most commonly associated injury was chest $(59.2 \%)$, head $(33.3 \%)$, spleen $(11.1 \%)$ and kidney $(3.7 \%)$. Liver related complications included biloma \& pseudo-aneurysm. The overall mortality was $(7.4 \%)$.

Conclusion: NOM of blunt liver injuries in haemodynamically stable patients is safe and feasible. Haemodynamic instability, generalized peritonitis during resuscitation or associated intra-abdominal organ injuries requires early surgical intervention. Liver related complications contribute to failure of NOM. Associated extra-abdominal and intra-abdominal injuries do not interfere with non-operative management.
\end{abstract}

Key Words: Liver trauma - Non-operative managementOperative management.

\section{Introduction}

THE liver is the most frequently injured abdominal organ despite of its protected location [1,2].

There is a change in management of liver trauma with improvement in outcomes, shifting from operative management to non-operative management with selective operative intervention in hemodynamically unstable patients [3] .

Correspondence to: Dr. Mohamed H. Zaid,

E-Mail: hamdymhz@gmail.com
Triphasic Abdominal Computed Tomography scan is considered the most accurate method for diagnosis grade of liver injury in hemodynamically stable patients and guide in the management plan with different approaches [4].

Triphasic Abdominal CT scan can detect active bleeding (i.e., contrast extravasation \& blush), associated organ injuries, hemoperitoneum and pseudo-aneurysm [5] .

Angioembolization is used to support NOM of liver injury or after perihepatic packing technique in hemodynamically unstable patients $[4,6]$.

Angioembolization is an adjunct that increase success rate of NOM of liver trauma but it may be associated with complications such as liver abscess, liver necrosis or biloma [22]

Non-operative management of blunt livertrauma has less mortality than operative management [710].

Operative management is considered for the hemodynamically unstable patients with severe injuries or to treatother complications associated with liver injury [11-13].

Operative management approaches are perihepatic packing, selective vascular ligation and resectionor debridement [8-14].

\section{Patients and Methods}

\section{Patients:}

This is a concurrent cohort study conducted at Ain-Shams University Hospitals, in the periodfrom December 2017 to December 2019. Twenty-seven patients with blunt abdominal trauma with liver injuries admitted to the hepato-biliary unit were managed with non-operative conservative management, Angioembolization or operative intervention. 
Ethical approval was obtained from Al Demerdash ethical committee.

Inclusion criteria: All patients with Blunt liver trauma in both genders. (Age $>18$ years).

Exclusion criteria: Patients with penetrating abdominal injury and those were dead on arrival.

Clinical assessment: All patients were resuscitated according to the advanced Trauma Life Support guidelines (ATLS), patients demographics (age and gender), Mode of trauma, vital signs (pulse, blood pressure, Temperature), Glasgow Coma Score (GCS).

Investigations: Routine laboratory investigationscomplete blood count, liver functions, kidney functions, coagulation profile, and random blood sugar, Arterial blood gases, Focused Assessment with Sonography for Trauma (FAST) for early assessment of all patients to detecthemoperitoneum \& Triphasicpelvi-abdominal C.T. for hemodynamically stable patients.

\section{Our management:}

Non-operative management:

1- Hemodynamically stable patients.

2- Patients with negative FAST.

3- No active blush in Triphasicpelvi-abdominal C.T.

4- No associated injured organs.

\section{Angioembolization:}

1- Presence of arterial blush in C.T. either liver or spleen in hemodynamically stable patients.
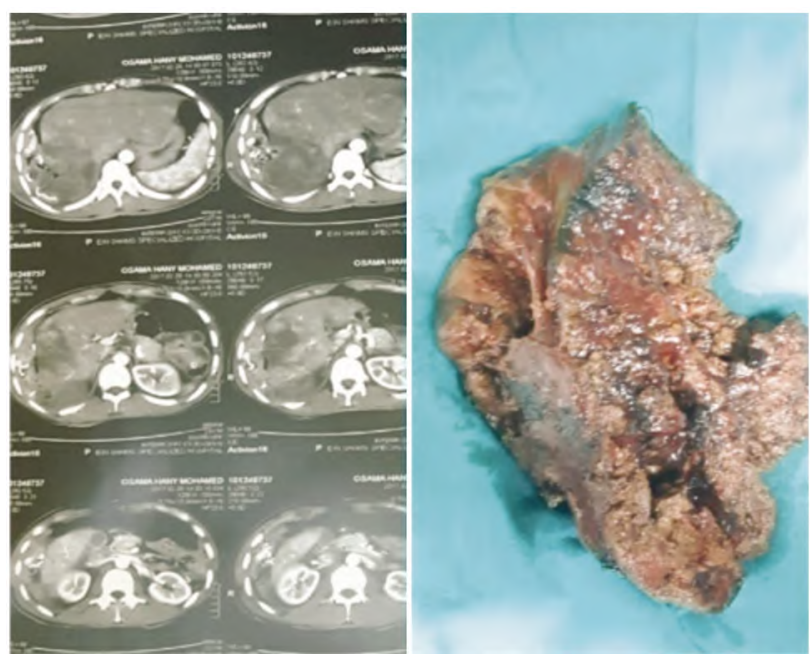

Fig. (1): Depacking \& rt. posterior segmetectomy (arterial phase).
2- Presence of arterio-venous fistula or pseudoaneurysm who presented with rebleeding or hemobilia.

3- Post-operative bleeding after perihepatic packing in high grade injury patient.

\section{Operative management:}

1- Hemodynamically unstable patients.

2- Patients with positive FAST and hemodynamic instability.

3- Hemodynamically unstable patients after angioembolizations.

4- High grade liver injury.

5- Associated organ injury.

6- Patients referred with peri-hepatic packing for de-packing after 48 hours to 72 hours.

7- Deteriorating patients after Non-operative management.

Operative techniques (Figs. 1,2):

1- Perihepatic packs in high grade injury or UNcontrollable bleeding.

2- Segmentectomy or formal hepatectomy.

3- Liver suturing or electrocautery coagulation of oozingsurface.

\section{Follow-up:}

Patients were followed-up every week till removal of stitches then for 6 months for any complications (wound infection, late biliary complications, pseudoaneurysm, arteriovenous fistula and incisional hernia).

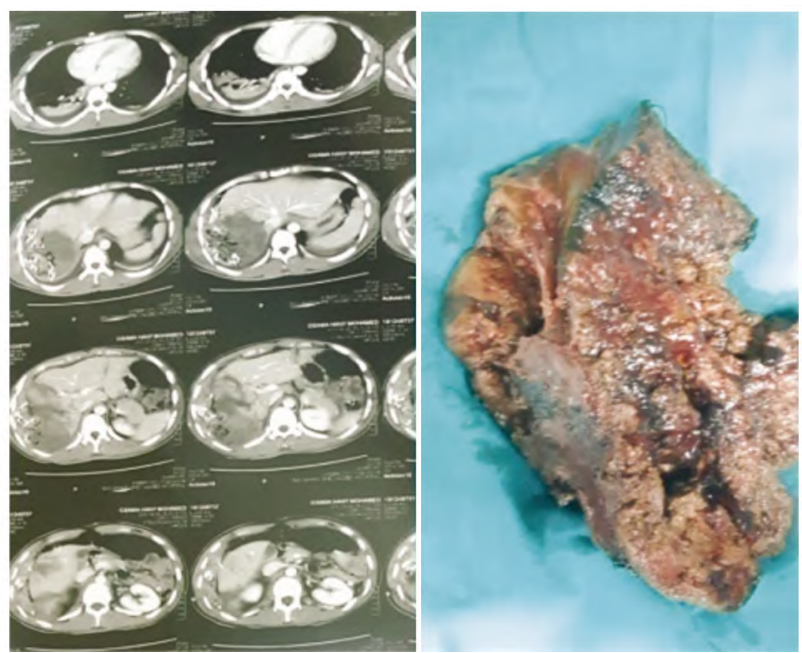

Fig. (2): Depacking \& segmentectomy (Rt. posterior portal injury). 


\section{Results}

Preoperative findings:

Patient characteristics:

Our study included twenty seven patients presented to our department with blunt abdominal trauma with variable grades of liver injuries. Their age ranged from (18-62 years) (mean 31.1 \pm 7.51 years). Nineteen male patients $(65.5 \%)$, eight female patients $(29.6 \%)$. Two patients $(7.4 \%)$ were diabetic; three patients $(11.1 \%)$ were hypertensive. motor car accident is the most common cause of injury (42\%), falling from height $(14.8 \%)$ and pedestrian struck $(7.4 \%)$.

Patient characteristics are illustrated in Table (1).

Table (1): Patient characteristics.

\begin{tabular}{llllll}
\hline & $\begin{array}{c}\text { Non operative } \\
\text { management } \\
\text { No.=20 }\end{array}$ & $\begin{array}{c}\text { Operative } \\
\text { management } \\
\text { No.=7 }\end{array}$ & Test value & $p$-value & Sig. \\
\hline $\begin{array}{l}\text { Age: } \\
\text { Mean } \pm \text { SD } \\
\text { Range }\end{array}$ & $\begin{array}{l}\text { Mean 32.1 } \\
18-62\end{array}$ & $\begin{array}{l}\text { Mean } 31.5 \pm 7.0 \\
18-62\end{array}$ & -0.1915 & $<0.05$ & NS \\
$\begin{array}{l}\text { Co-morbidities: } \\
\text { HTN }\end{array}$ & $2(10 \%)$ & $1(14.3 \%)$ & -0.1824 & $<0.05$ & NS \\
D.M. & $1(5 \%)$ & $1(14.3 \%)$ & & & \\
\hline$p$-value $>0.05:$ Non significant. & $p$-value $<0.05$ : Significant. & $p$-value $<0.01$ : Highly significant.
\end{tabular}

Clinical assessment and blood transfusion:

A prospective cohort enrolled twenty-seven patients with blunt liver trauma admitted to the hepato-biliary unit were managed with nonoperative conservative management, Angioembolization or operative intervention. All patientswere resuscitated according to the advanced Trauma Life Support guidelines (ATLS), Mode of trauma, vital signs (pulse, bloodpressure, Temperature), Glasgow Coma Score $>10$ in Eighteen patients (90\%) in NOM group, Four patients (57.1) in OM group had GCS >10. (GCS assessment in Table 2). All patients underwent FAST for assessment of abdominal collection. Pelvi-abdominal C.T. with contrast was done in Twenty two $(81.4 \%)$ hemodynamically stable patients to assess grade of liver injury and any associated abdominal injury (Table 3 ).

Seven patients $(25.9 \%)$ presented with Grade I liver injury were managed non-operatively, Six patients $(22.2 \%)$ presented with Grade II liver injury were managed non-operatively, Five patients had Grade III liver injury were managed nonoperatively, Six patients (22.2\%) presented with Grade IV liver injury two patients of them were managed non-operatively and the other four patients underwent emergent surgery, 2 patients (7.4\%) with Grade V and 1 patient (3.7\%) underwent emergent surgery due to hemodynamic instability. (Table 3).

The most commonly associated injury was chest in Sixteen patients $(59.2 \%)$, head injury in Nine patients $(33.3 \%)$, spleen injury in Three patients $(11.1 \%)$ and kidney injury in one patient $(3.7 \%)$.
Patients associated injuries were illustrated in Table (4). Twenty one patients $(77.7 \%)$ received blood transfusion (Table 5).

Table (2): GSC score assessment $(<10)$.

\begin{tabular}{lcc}
\hline $\begin{array}{l}\text { Overall } \\
(\mathrm{N}=27)\end{array}$ & $\begin{array}{c}\text { NOM } \\
(\mathrm{N}=20)\end{array}$ & $\begin{array}{c}\text { OM } \\
(\mathrm{N}=7)\end{array}$ \\
\hline $22(81.5 \%)$ & $18(90 \%)$ & $4(57.1 \%)$ \\
\hline
\end{tabular}

Table (3): Grades of liver injury.

\begin{tabular}{llll}
\hline & $\begin{array}{c}\text { Overall } \\
(\mathrm{N}=27)\end{array}$ & $\begin{array}{c}\text { NOM } \\
(\mathrm{N}=20)\end{array}$ & $\begin{array}{l}\text { OM } \\
(\mathrm{N}=7)\end{array}$ \\
\hline Grade I & $7(25.9 \%)$ & $7(35 \%)$ & $0(0 \%)$ \\
Grade II & $6(22.2 \%)$ & $6(30 \%)$ & $0(0 \%)$ \\
Grade III & $5(18.5 \%)$ & $5(25 \%)$ & $0(0 \%)$ \\
Grade IV & $6(22.2 \%)$ & $2(10 \%)$ & $4(57.1 \%)$ \\
Grade V & $2(7.4 \%)$ & & $2(28.57 \%)$ \\
Grade VI & $1(3.7 \%)$ & & $1(14.3 \%)$ \\
\hline
\end{tabular}

Table (4): Patients associated injury.

\begin{tabular}{llll}
\hline & $\begin{array}{c}\text { Overall } \\
(\mathrm{N}=27)\end{array}$ & $\begin{array}{c}\mathrm{NOM} \\
(\mathrm{N}=20)\end{array}$ & $\begin{array}{c}\mathrm{OM} \\
(\mathrm{N}=7)\end{array}$ \\
\hline Chest & $16(59.2 \%)$ & $11(55 \%)$ & $5(71.42 \%)$ \\
Head & $9(33.3 \%)$ & $5(25 \%)$ & $4(57.1 \%)$ \\
Spleen & $3(11.1 \%)$ & $1(5 \%)$ & $3(28.6 \%)$ \\
Kidney & $1(3.7 \%)$ & $0(0 \%)$ & $1(14.3 \%)$ \\
\hline
\end{tabular}

Table (5): Blood transfusion (per unit).

\begin{tabular}{lcccc}
\hline NOM & OM & Test value & $p$-value & Sig. \\
\hline $1.4 \pm 1.2$ & $5.4 \pm 2.5$ & 4.072 & $<0.001$ & HS \\
\hline
\end{tabular}

$p$-value $>0.05$ : Non significant.

$p$-value <0.05: Significant.

$p$-value $<0.01$ : Highly significant. 


\section{Non-operative management:}

Twenty patients (74\%) were managed Nonoperatively. Nineteen patients (95\%) had successful Non-operative management but one patient (5\%) needed delayed operation due to delayed bleeding from hepatic hematoma and operated successfully. The mean hospital stay was $8.82 \pm 3.4$ days (Table $6)$.

One patient (5\%) died from associated head injury and ARDS in ICU.

\section{Operative management:}

Seven patients $(25.9 \%)$ underwent emergent surgery either Perihepatic packing in high grade injury or UN controllable bleeding, Segmentectomy or formal hepatectomy.

Four patients $(57.1 \%)$ underwent Perihepatic packing in high grade injury and UN controllable bleeding, after 48 hours re-exploration for depacking, 3 patients underwent hepatectomy after depacking (Figs. 3,4), one patient underwent only depacking and liver suturing.

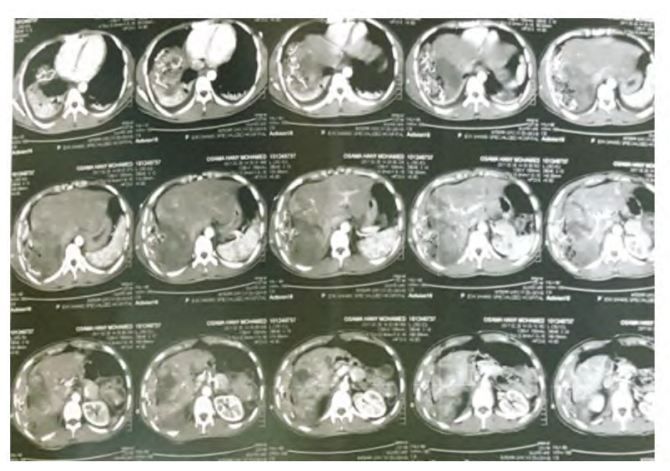

Fig. (3): Perihepatic packing.

Table (6): Hospital stay.

\begin{tabular}{ccccc}
\hline NOM & OM & Test value & $p$-value & Sig. \\
\hline $8.82 \pm 3.4$ days & $13.4 \pm 1.9$ days & 4.379 & $<0.001$ & HS \\
\hline
\end{tabular}

$p$-value $>0.05$ : Non significant.

$p$-value $<0.05$ : Significant.

$p$-value $<0.01$ : Highly significant

\section{Discussion}

Our study is to discuss our experience in Operative and Non-Operative management of Blunt liver Trauma.

The liver is the most frequently injured abdominal organ despite of its protected location [1,2].

There is a change in management of liver trauma with improvement in outcomes, shifting from operative management to non-operative management
Two patients (28.57\%) underwent hepatectomy. One patient (14.28\%) underwent liver sutures and hemostasis.

Hemodynamic instability, intra-abdominal collection, and high grade liver injuryand associated splenic injury were indications for surgery. The mean hospital stay was $13.4 \pm 1.9$ days (Table 6).

One patient (14.3\%) died from uncontroll able bleeding after perihepatic packing (grade VI) and had severe head injury.

\section{Complications and outcomes:}

Overall pneumonia (12\%), ARDS (3.7\%), sepsis $(11.1 \%)$ were the most common hospital complications.

Liver related complications were biloma in two patients $(7.4 \%)$ that were treated with U/S guided pigtail and ERCP. One patient developed pseudoaneurysm (3.7\%) who presented with re-bleeding and hemobilia managed by Angioembolization. The overall mortality was (7.4\%).

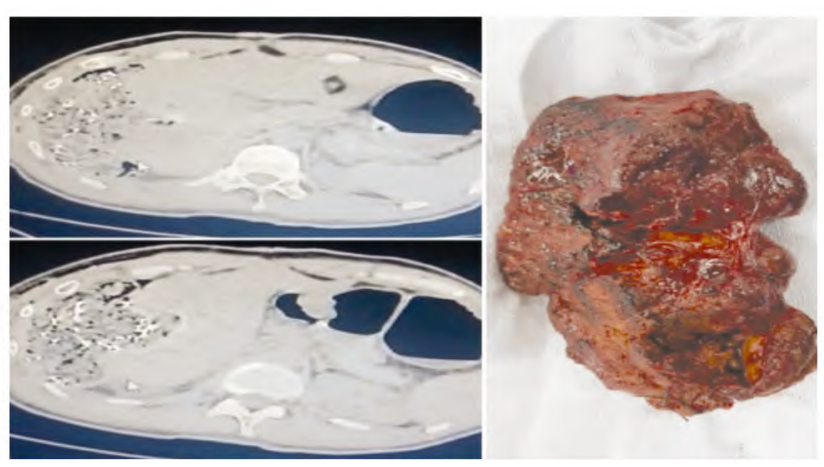

Fig. (4): Perihepatic packing then hepatectomy after 48 hours.

with selective operative intervention in hemodynamically unstable patients [3]

Mode of Liver injury differs according to community factors and socio-demographic $[\mathbf{1 5 , 2 0 ]}$

In our study motor car accident is the most common cause of injury (42\%), falling from height $(14.8 \%)$ and pedestrian struck $(7.4 \%)$.

Other studies showed that liver trauma may be associated with extra-abdominal injuries involving head and chest as well as fractures of pelvis and long bones [21], in our study The most commonly associated injury was chest in Sixteen patients $(59.2 \%)$, head injury in Nine patients $(33.3 \%)$, spleen injury in Three patients (11.1\%) and kidney injury in one patient $(3.7 \%)$.

Beardsley et al., [15] reported that $80 \%$ of patients with liver injuries can be managed non- 
operatively; in this study twenty patients (74\%) were managed Non-operatively. Nineteen patients $(95 \%)$ had successful Non-operative management but one patient $(5 \%)$ needed delayed operation due to delayed bleeding from hepatic hematoma and operated successfully.

There is an improvement in non-operative management in comparison to study by Bernardo et al., [11] that report that $60.8 \%$ of cases were managed non-operatively with a failure rate of $15 \%$.

Østerballe et al., [16] reported that $4 \%$ of pseudo aneurysm on follow-up of 188 patients that wassimilar to our study that reported $3.7 \%$ developed pseudo aneurysm which presented with re-bleeding and hemobilia managed by Angioembolization. The severity of liver injury was not related to development of pseudo aneurysm.

Angioembolization is an adjunct that increase success rate of NOM of liver trauma but it may be associated with complications such as liver abscess, liver necrosis or biloma [22]

Carrillo et al., [23] ; reported that liver related complications after blunt abdominal trauma was $2.8 \%$ of patients developed biloma. Bala et al., [24] ; reported that 16 patients of 398 patients (4\%) developed biloma and bile leak after liver trauma that managed with U/S guided pigtail and ERCP. Three patients of 398 patients $(0.7 \%)$ developed pseudoaneurysmwho presented with re-bleeding managed by Angioembolization. In our study Liver related complications were biloma in two patients (7.4\%) that were treated with U/S guided pigtail and ERCP. One patient developed pseudoaneurysm (3.7\%) who presented with re-bleeding and hemobilia managed by Angioembolization.

Damage control concept is valuable in Hemodynamically unstable patients after blunt liver trauma as polytraumatic patients [17].

Ghnnam et al., [18] reported that less blood transfusion in patients managed non-operatively, similar to our study patients who managed nonoperatively needed $1.4 \pm 1.2$ unit of packed RBCs while $5.4 \pm 2.5$ unit of packed RBCs needed in patients who managed operatively.

Ghnnam et al., study [18], reported that there is no difference in length of hospital stay between NOM and OM. In our study there is difference between two groups in length of hospital stay.

The overall mortality in this study was $(7.4 \%)$ similar to mortality $(7.8 \%)$ that reported by Afifi et al., [19], however in study in Saudi Arabia reported lower mortality rate $3.5 \%$ [18].

Multidisciplinary team that includes surgeons, intervention radiologist, endoscopists and ICU team has a very important role in management of liver trauma patients.

\section{Conclusion:}

NOM of blunt liver injuries in haemodynamically stable patients is safe and feasible. Haemodynamic instability, generalized peritonitis during resuscitation or associated intra-abdominal organ injuries requiresearly surgical intervention. Liver related complications contribute to failure of NOM. Associated extra-abdominal and intra-abdominal injuries do not interfere with non-operative management.

Acknowledgement: The authors declare that they have no conflict of interest.

\section{References}

1- OCHIAI T., IGARI K., YAGI M., ITO H., KUMAGAI Y., IIDA M., MATSUMOTO A., KUMADA Y., SHINOHARA K. and YAMAZAKI S.: Treatment strategy for blun thepatic trauma: Analysis of 183 consecutive cases Hepatogastroenterology, 58 (109): 1312-1315, 2011.

2- MORRISON J.J., BRAMLEY K.E. and RIZZO A.G.: Liver trauma-operative management. J. R. Army Med. Corps, 157 (2): 136-144, 2011.

3- KOZAR R.A., FELICIANO D.V., MOORE E.E., MOORE F.A., COCANOUR C.S., WEST M.A., DAVIS J.W. and McINTYRE R.C. Jr.: Western Trauma Association/critical decisions in trauma: Operative management of adult blunt hepatic trauma. J. Trauma, 71(1): 1-5, 2011.

4- SALTZHERR T.P., VAN DER VLIES C.H., VAN LIENDEN K.P., BEENEN L.F., PONSEN K.J., VAN GULIK T.M. and GOSLINGS J.C.: Improved outcomes in the non-operative management of liver injuries. HPB (Oxford), 13 (5): 350-5, 2011.

5- BUCI S., TORBA M., GJATA A., KAJO I., BUSHI G. and KAGJINI K.: The rate of success of the conservative management of liver trauma in a developing country. World J. Emerg. Surg., 12: 24, 2017.

6- CHATOUPIS K., PAPADOPOULOU G. and KASKARELIS I.: New technology in the management Oliver trauma. Ann. Gastroenterol., 26 (1): 41-4, 2013.

7- SARTORELLI K.H., FRUMIENTO C., ROGERS F.B., et al.: Non-operative management of hepatic, splenic, and renal injuries in adults with multiple injuries. J. Trauma, 49: 56-61, 2000.

8- RICHARDSON J.D., FRANKLIN G.A., LUKAN J.K., et al.: Evolution in the management of hepatic trauma: A 25 year perspective. Ann. Surg., 232: 324-30, 2000.

9- CHRISTMAS A.B., WILSON A.K., MANNING B., et al.: Selective management of blunt hepatic injuries including non-operative management is a safe and effective strategy. Surgery, 138: 606-11, 2005. 
10- TINKOFF G., ESPOSITO T., REED J., et al.: American Association for the Surgery of Trauma organ injury scale I: spleen, liver, and kidney, validation based on the national trauma data bank. J. Am. Coll. Surg., 207: 646-55, 2008.

11- BERNARDO C.G., FUSTER J., BOMBUY E., SANCHEZ S., FERRER J., LOERA M.A., MARTI J., FONDEVILA C., ZAVALA E. and GARCIA-VALDECASAS J.C.: Treatment of liver trauma: Operative or conservative management. Gastroenterology Res., 3 (1): 9-18, 2010.

12- PAYDAR S., MAHMOODI M., JAMSHIDI M., NIAKAN H., KESHAVARZ M., MOEENVAZIRI N., et al.: Perihepatic packing versus primary surgical repair in patients with blunt liver trauma; an 8-year experience. Bull Emerg. Trauma, 2 (3): 103-9, 2014.

13- COCCOLINI F., CATENA F., MOORE E.E., IVATURY R., BIFFL W., PEITZMAN A., COIMBRA R., RIZOLI S., KLUGER Y., ABU-ZIDAN F.M., CERESOLI M., MONTORI G., SARTELLI M., WEBER D., FRAGA G., NAIDOO N., MOORE F.A., ZANINI N. and ANSALONI L.: WSES classification and guidelines for liver trauma. World J. Emerg. Surg., 11: 50, 2016.

14- PAYDAR S., MAHMOODI M., JAMSHIDI M., NIAKAN H., KESHAVARZ M., MOEENVAZIRI N., et al.: Perihepatic packing versus primary surgical repair in patients with blunt liver trauma; an 8-year experience. Bull Emerg. Trauma, 2 (3): 103-9, 2014.

15- BEARDSLEY C. and GANANADHA S.: An overview of liver trauma. MSJA, 3: 5-10, 2011.

16- ØSTERBALLE L., HELGSTRAND F., AXELSEN T., et al.: Hepatic pseudoaneurysm after traumatic liver injury; is CT follow-up warranted? Journal of Trauma Management \& Outcomes, 8: 18, 2014.
17- FELICIANO D.V.: Abdominal trauma revisited. Am. Surg., 83 (11): 1193-202, 2017.

18- GHNNAM W.M., ALMASRY H.N. and GHANEM M.A.: Non-operative management of blunt liver trauma in a level II trauma hospital in Saudi Arabia. Int. J. Crit. Illn. Inj. Sci., 3 (2): 118-23, 2013.

19- IBRAHIM AFIFI, SHERAZ ABAYAZEED, AYMAN EL-MENYAR, HUSHAM ABDELRAHMAN, RUBEN PERALTA and HASSAN AL-THANI: BMC Surgery, 2018.

20- SALEH A.F., AL SAGEER E. and ELHENY A.: Management of Liver Trauma in Minia university hospital, Egypt. Indian J. Surg., 78 (6): 442-7, 2016.

21- MALHOTRA A.K., FABIAN T.C., CROCE M.A., et al.: Blunt hepatic injury: A paradigm shift from operative to non-operative management in the 1990's. Ann. Surg., 231: 804-13, 2000.

22- ASFAR S., KHOURSHEED M., AL-SALEH M., ALFAWAZ A.A., FARGHALY M.M. and NUR A.M.: Management of Liver Trauma in Kuwait. Med. Princ Pract., 23: 160-6, 2014.

23- CARRILLO E.H., WOHLTMANN C., RICHARDSON J.D. and POLK H.C. Jr.: Evolution in the treatment of complex blunt liver injuries. Curr. Probl. Surg., 38 (1): 1-60, 2001.

24- BALA M., ABU GAZALLA S., ALMOGY G., et al.: Complications of high grade liver injuries: Management and outcome with focus on bile leaks. Scandinavian Journal of Trauma, Resuscitation and Emergency Medicine, 20: 20, 2012. 


\section{دراسة لتقييم العلاج الجراحى

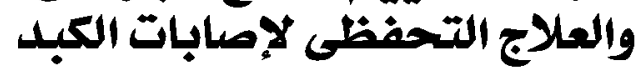

بالرغم من وضع الكبد فى الجسم الا أنه عرضه لإصابة نتيجة الحوادث وفى السنوات الأخيرة حدث تغير في علاج إصابات الكبد من العلاج

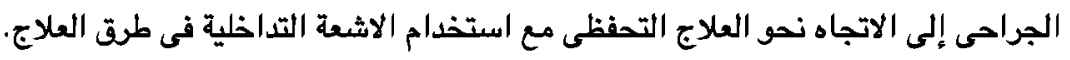
فى حالات إصابات الكبد يتم تقييم حالة المريض العامة والعلامات الحيوية المريض أولاً. ثم يتم عمل أشعة تليفزيونية لتصديد اذا كان هناك تجمع دموى بالبطن أم لات.

يتم استخدام الاشعة المقطعية بالصبغة لتقييم وضع اصابة الكبد في الحالات المستقرة لتحديد مكان الاصابة بالكبد وتصديد وجود نزيف باليف من الكبد أو تجمع دموى بالبطن أووجود إصابات أخرى بالبطن.

يتم عمل الاسعافات الأولية لكل حالات الاصابات الكبدية وتخضع العلاج التحفظى فى حالة استقرار العلامات الحيوية ونحتاج للتدخل الجراحى فى حالة عدم استقرار العلامات الحيوية بعد عمل الاسعافات الأولية.

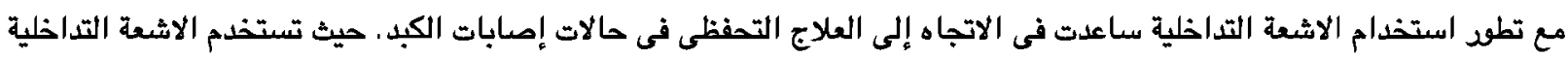

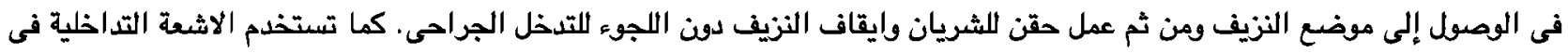
غلق التمدد الشريانى الناتج عن إصابات الكبد أو بعد التدخل الجراحى فى حالات إصابات الكبات الكبد.

التذخل الجراحى يستخدم فى حالات إصابات الكبد مع وجود تجمع دموى بالبطن أو عدم استقرار اللعلامات الهيوية للمريض أو وجول

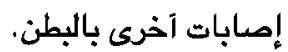

التخل الجراحى لإصابات الكبد يشمل استئصال جزء من الكبد أو استئصال فص من الكبد أو وضع فوط جراحية اللسيطرة على النزيف ومتابعة المريض لمدة يومين ومن ثم ازالة الفوط بعد توقف النزيف.

مع تطود العلاج التحفظى ومتابعة المريض باستخدام الاشعة المقطعية وتطود الاشعة التداخلية قل الاتجاه إلى التخل الجراحى فى حالات إصابات الكبد. 